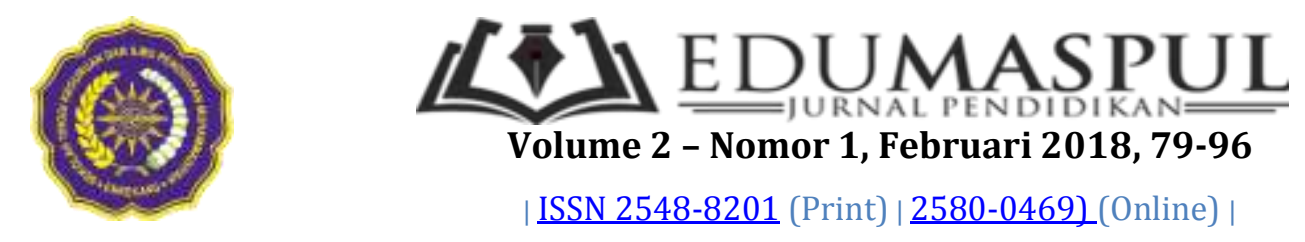

\title{
PENERAPAN PEMBELAJARAN PENDIDIKAN AGAMA ISLAM DALAM MEMBENTUK KARAKTER PRIBADI YANG ISLAMI
}

\author{
Elihami Elihami \\ STKIP Muhammadiyah Enrekang, Indonesia \\ Email: elihamid@ymail.com \\ Abdullah Syahid \\ Universitas Muhammadiyah Parepare, Indonesia
}

\begin{abstract}
Abstrak
Penelitian ini membahas tentang penerapan pendidikan agama Islam pada sebagai upaya pembentukan kepribadian muslim peserta didik yang islami. Jenis penelitian yang digunakan adalah penelitian kualitatif. Pendekatan penelitian menggunakan interdisipliner, antara lain: pendekatan manajeman, pedagogis, sosiologis, dan psikologis. Sumber data primer dari penelitian ini adalah guru Pendidikan Agama Islam. Sumber data sekunder dalam penelitian ini berupa data profil sekolah, teori tentang konsep strategi pembelajaran, teori pendidikan agama Islam, dan teori pembentukan kepribadian muslim. Teknik pengumpulan data menggunakan observasi, wawancara, dan dokumentasi. Teknik analisis data menggunakan tahapan reduksi data, penyajian data, dan penarikan kesimpulan. Hasil penelitian ditemukan bahwa strategi pembelajaran Pendidikan Agama Islam dalam pembentukan kepribadian muslim peserta didik menggunakan dua strategi pembelajaran, yaitu pembelajaran langsung dan pembelajaran tidak langsung.
\end{abstract}

Kata Kunci: Strategi Pembelajaran; Kepribadian Muslim;Pendidikan Agama Islam; Peserta didik

\begin{abstract}
This study discusses the strategy of Islamic religious education teachers in the teaching of Islamic Education as efforts to establish the Islamic personality of the students. This type of research is qualitative research. Interdisciplinary research approach used, among other things: management approach, pedagogical, sociological, and psychological. Sources of primary data from this study were teachers of Islamic education. Secondary data sources in this study a school profile data, theories on the concept of the learning strategies, Islamic religious of education theory, and the theory of the formation of Muslim personality. Data collection techniques using observation, interviews, and documentation. Data were analyzed using the stages of data reduction, data presentation, and conclusion. The research found that the learning strategies of Islamic education in shaping Muslim personality of students use two strategies of learning, ie learning direct and indirect learning.
\end{abstract}

Keywords: Learning Strategies; Personality Muslim; Islamic Education; Learners

\section{A. Pendahuluan}

Pendidikan Agama Islam sebagai suatu proses ikhtiyariyah mengandung ciri dan watak khusus, yaitu proses penanaman, pengembangan dan pemantapan nilai-nilai keimanan yang menjadi fundamen mentalspritual manusia dimana sikap dan tingkah lakunya termanifestasikan menurut kaidahkaidah agamanya. Nilai-nilai keimanan seseorang adalah keseluruhan pribadi yang 
menyatakan diri dalam bentuk tingkah laku lahiriah dan rohaniah, dan ia merupakan tenaga pendorong/penegak yang fundamental, bagi tingkah laku seseorang. ${ }^{1}$

Pendidikan Islam juga melatih kepekaan (sensibility) para peserta didik sedemikian rupa, sehingga sikap hidup dan prilaku didominasi oleh perasaan mendalam nilai-nilai etis dan spritual Islam. Mereka dilatih, sehingga mencari pengetahuan tidak sekedar untuk memuaskan keingintahuan intelelektual atau hanya untuk keuntungan dunia material belaka, tetapi juga untuk mengembangkan diri sebagai makhluk rasional dan saleh yang kelak akan memberikan kesejahteraan fisik, moral dan spritual bagi keluarga, masyarakat dan umat manusia. Pandangan ini berasal dari keimanan mendalam kepada Allah swt. ${ }^{2}$

Berdasarkan undang-undang sistem Pendidikan Nasional Nomor 20 tahun 2003 dijelaskan bahwa:

Pendidikan nasional bertujuan untuk mengembangkan potensi peserta didik agar menjadi manusia Indonesia seutuhnya yaitu manusia yang beriman dan bertaqwa kepada Tuhan Yang Maha Esa, memiliki pengetahuan dan keterampilan, berbudi pekerti yang luhur, sehat jasmani dan rohani, berkepribadian yang mantap, cerdas, kreatif, mandiri dan memiliki rasa tanggung jawab. ${ }^{3}$

Dalam upaya menanamkan perilaku keberagamaan terhadap peserta didik, maka sangat diharapkan kepada setiap lembaga pendidikan untuk memberikan pengaruh bagi pembentukan jiwa keagamaan pada anak. Namun besar

${ }^{1}$ H. M. Arifin, Kapita Selekta Pendidikan (Cet. IV; Jakarta: Bumi Aksara, 2000), h. 214.

${ }_{2}$ Fadhlan Mudhafir, Krisis Dalam Pendidikan Islam (Cet. I; Jakarta: Al-Mawardi Prima, 2000), h. 1.

Depdiknas, Undang-undang Sistem Pendidikan Nasional (Jakarta: Direktorat Jendral Pendi-dikan dan Kebudayaan, 2003), h. 6. kecilnya pengaruh yang dimaksud sangat tergantung pada berbagai faktor yang dapat memotivasi anak untuk memahami nilai-nilai agama. Sebab pendidikan agama pada hakekatnya merupakan pendidikan nilai. Oleh karena itu pendidikan agama lebih dititik beratkan pada bagaimana membentuk kebiasaan yang selaras dengan tuntunan agama. ${ }^{4}$

Pengaruh pembentukan jiwa keagamaan dan perilaku keberagamaan pada lembaga pendidikan, khususnya pada lembaga pendidikan formal (sekolah) banyak tergantung dari bagaimana karakteristik pendidikan agama yang diberikan di sekolah tersebut. Hal tersebut dikarenakan sekolah dalam perspektif Islam, berfungsi sebagai media realisasi pendidikan berdasarkan tujuan pemikiran, aqidah dan syariah dalam upaya penghambaan diri terhadap Allah dan mentauhidkan-Nya sehingga manusia terhindar dari penyimpangan fitrahnya. ${ }^{5}$ Kaitannya dengan itu, dalam upaya pembentukan pribadi muslim yang saleh, maka pendidikan melalui sistem persekolahan patut diberikan penekanan yang istimewa. Hal ini disebabkan oleh pendidikan sekolah mempunyai program yang teratur, bertingkat dan mengikuti syarat yang jelas dan ketat. Hal ini mendukung bagi penyusunan program pendidikan Islam yang lebih akomodatif. ${ }^{6}$

4 Jalaluddin, Psikologi Agama (Cet.I; Jakarta: Grafindo Persada, 1996), h. 206.

5 Abdurrahman al-Nahdlawi, Ushul alTarbiyah al-Islamiyah wa Asalibuha fi al-Bayt wa al-Madrasah wa al-Mujtama' diterjemahkan oleh Shibabuddin dengan judul "Pendidikan Islam di Rumah, Sekolah dan Masyarakat" (Cet. II; Jakarta: Gema Insani Press, 1995), h. 152.

6 Syarifuddin Ondeng, Islam dalam Berbagai Dimensi; Kajian tentang Agama, Sejarah dan Pendidikan (Makassar: Berkah Utami, 2004), h. 160 . 
Guru dalam menggunakan strategi pembelajaran, hendaknya menyesuaikan dengan kondisi dan suasana kelas serta tentunya guru dituntut perannya lebih banyak menggunakan strategi pembelajaran yang variatif. Setiap strategi pembelajaran ada kelebihan dan kekurangannya. Agar tidak terjadi kegiatan pembelajaran yang membosankan bagi peserta didik, seorang guru perlu menciptakan strategi pembelajaran yang baik dan selaras dengan kebutuhan peserta didik tersebut.

Berdasarkan fenomena tersebut, penulis menganggap perlu untuk melakukan penelitian untuk melihat strategi yang diterapkan guru pendidikan agama Islam dalam rangka menghasilkan output yang handal, terutama dalam menciptakan peserta didik yang berakhlak dan berwawasan keislaman. Begitu juga, peneliti secara khusus akan meneliti strategi pembelajaran yang diterapkan oleh guru dalam mengajarkan mata pelajaran Pendidikan Agama Islam sebagai dasar utama dalam mewujudkan peserta didik yang berkepribadian muslim.

\section{B. Tinjauan Pustaka}

\section{Konsep Strategi Pembelajaran}

Istilah strategi pada mulanya digunakan dalam dunia militer yang diartikan sebagai cara penggunaan seluruh kekuatan militer untuk memenangkan suatu peperangan. Seorang yang berperan dalam mengatur strategi, untuk memenangkan peperangan sebelum melakukan suatu tindakan, ia akan menimbang bagaimana kekuatan pasukan yang dimilikinya baik dilihat dari kuantitas maupun kualitas; misalnya kemampuan setiap personal, jumlah dan kekuatan persenjataan, motivasi pasukannya dan lain sebagainya. ${ }^{7}$

\footnotetext{
7 Wina Sanjaya, Kurikulum dan Pembelajaran, Teori dan Praktik Pengembangan KTSP (Cet. I; Jakarta: Kencana, 2008), h. 293. Lihat
}

Menurut J.R. David dalam dunia pendidikan strategi diartikan sebagai " $a$ plan, method, or series of activities designed to achieves a particular educational goal". 8 Jadi dengan demikian strategi pembelajaran dapat diartikan sebagai suatu perencanaan yang berisi tentang rangkaian kegiatan yang didesain untuk mencapai tujuan pendidikan tertentu. Menurut Darsono yang dikutip Mustahu bahwa pembelajaran dapat dibedakan menjadi dua, yaitu secara umum dan secara khusus. Pengertian pembelajaran secara umum adalah suatu kegiatan yang dilakukan oleh pendidik sedemikian rupa, sehingga tingkah laku peserta didik berubah ke arah yang lebih baik. Sedangkan pembelajaran secara khusus adalah suatu kegiatan yang dilakukan secara tidak sadar dan tidak sengaja. Oleh karena itu pembelajaran pasti mempunyai tujuan pembelajaran (learning), merupakan proses perubahan yang relatif konstan dalam tingkah laku yang terjadi karena adanya sesuatu pengalaman atau latihan. ${ }^{9}$

Pembelajaran ialah membelajarkan peserta didik menggunakan asas pendidikan maupun teori belajar, yang merupakan penentu utama keberhasilan pendidikan. Pembelajaran merupakan proses komunikasi dua arah, mengajar dilakukan oleh pihak guru sebagai pendidik, sedangkan belajar dilakukan oleh peserta didik atau murid. Sedangkan menurut Corey sebagaimana yang dikutip oleh Syaiful Sagala Pembelajaran adalah suatu proses dimana lingkungan seseorang secara disengaja dikelola untuk memungkinkan ia turut serta dalam tingkah laku tertentu dalam

juga Wina Sanjaya, Strategi Pembelajaan Berorientasi Standar Proses Pendidikan (Cet. IV; Jakarta: Prenada Media Group, 2008), h. 125.

${ }^{8}$ Wina Sanjaya, Kurikulum dan Pembelajaran, op. cit., h. 294.

${ }^{9}$ Mastuhu, Menata Ulang Pemikiran Sistem Pendidikan (Yogyakarta: S.I. Press, 2004), h. 20. 
kondisikondisi khusus atau menghasilkan respons terhadap situasi tertentu, pembelajaran merupakan subset khusus dari pendidikan. ${ }^{10}$ Pembelajaran merupakan aktualisasi kurikulum yang menuntut guru dalam menciptakan dan menumbuhkan kegiatan peserta didik sesuai dengan rencana yang telah diprogramkan. ${ }^{11}$

Berdasarkan beberapa definisi pembelajaran tersebut, dapat dipahami bahwa, pembelajaran adalah proses yang disengaja dirancang untuk menciptakan terjadinya aktivitas belajar dalam diri individu. Dengan kata lain, pembelajaran merupakan sesuatu hal yang bersifat eksternal dan sengaja dirancang untuk mendukung terjadinya proses belajar internal dalam diri individu.

Kemp menjelaskan bahwa strategi pembelajaran adalah suatu kegiatan pembelajaran yang harus dikerjakan pendidik dan peserta didik agar tujuan pembelajaran dapat dicapai secara efektif dan efisien. Senada dengan pendapat di atas, Dick and Carey juga menyebutkan bahwa strategi pembelajaran itu adalah suatu set materi dan prosedur pembelajaran yang digunakan secara bersama-sama untuk menimbulkan hasil belajar pada peserta didik. $^{12}$

Dari penjelasan di atas, maka dapat ditentukan bahwa suatu strategi pembelajaran yang diterapkan guru akan tergantung pada pendekatan yang digunakan; sedangkan bagaimana menjalankan strategi itu dapat ditetapkan berbagai metode pembelajaran. Dalam upaya menjalankan metode pembelajaran guru dapat menentukan teknik yang dianggapnya relevan dengan metode,

10 Syaiful Sagala, Konsep dan Makna Pembelajaran (Bandung: Alfabeta, 2003), h. 61.

${ }^{11}$ E. Mulyasa, Kurikulum Tingkat Satuan Pendidikan (Bandung: Remaja Rosdakarya, 2006), h. 90.

${ }^{12}$ Ibid., h. 294. dan penggunaan teknik itu setiap guru memiliki taktik yang mungkin berbeda antara guru yang satu dengan yang lain.

\section{Pertimbangan Pemilihan Strategi Pembelajaran \\ Pembelajaran pada dasarnya adalah} proses penambahan informasi dan kemampuan baru. Ketika kita berpikir informasi dan kemampuan apa yang harus dimiliki oleh peserta didik, maka pada saat itu juga kita semestinya berpikir strategi apa yang harus dilakukan agar semua itu dapat tercapai secara efektif dan efisien. Ini sangat penting untuk dipahami, sebab apa yang harus dicapai dalam menentukan strategi pembelajaran guru pun selalu menggunakan strategi pembelajaran yang lebih dari satu. Pemakaian strategi yang satu digunakan untuk mencapai tujuan yang satu, sementara penggunaan strategi yang lain, juga digunakan untuk mencapai tujuan yang lain. ${ }^{13}$

\section{Prinsip-prinsip Penggunaan Strategi Pembelajaran}

Yang dimaksud dengan prinsipprinsip dalam menggunakan strategi pembelajaran adalah bahwa tidak semua strategi pembelajaran cocok digunakan untuk mencapai semua tujuan dan semua keadaan. Setiap strategi memiliki kekhasan sendiri-sendiri. Hal ini seperti yang dikemukakan oleh Killen: "No teaching strategy is better than others in all circumtances, so you have to be able to use a variety of teaching strategies,; and make rational decisions about when each of the teaching strategies is likely to most effective". ${ }^{14}$

${ }^{13}$ Syaiful Bahri Djamarah (et.al.), Konsep Belajar dan Pembelajaran (Cet. III; Jakarta: Rineka Cipta, 2006), h. 75.

14 Wina Sanjaya, Strategi Pembelajaan Berorientasi Standar Proses Pendidikan, op. cit,. h. 131. 
Apa yang dikemukakan Killen itu jelas bahwa guru harus mampu memilih strategi yang dianggap cocok dengan keadaan. Oleh sebab itu, guru perlu memahami prinsip-prinsip umum penggunaan strategi pembelajaran sebagai berikut:

\section{a. Berorientasi pada Tujuan}

Dalam sistem pembelajaran tujuan merupakan komponen yang utama. Segala aktivitas guru dan peserta didik, mestilah diupayakan untuk mencapai tujuan yang telah ditentukan. Ini sangat penting, sebab mengajar adalah proses yang bertujuan. Oleh karenanya keberhasilan suatu strategi pembelajaran dapat ditentukan dari keberhasilan peserta didik mencapai tujuan pembelajaran.

\section{b. Aktivitas}

Belajar bukanlah menghafal sejumlah fakta atau informasi. Belajar adalah berbuat; memperoleh pengalaman tertentu sesuai dengan tujuan yang diharapkan. Karena itu, strategi pembelajaran harus dapat mendorong aktivitas peserta didik. Aktivitas tidak dimaksudkan terbatas pada aktivitas fisik, akan tetapi juga meliputi aktivitas yang bersifat psikis seperti aktivitas mental. Guru sering lupa dengan hal ini. Banyak guru yang terkecoh oleh sikap peserta didik yang pura-pura aktif padahal sebenarnya tidak.

\section{c. Individualitas}

$$
\text { Mengajar adalah usaha }
$$
mengembangkan setiap individu peserta didik. Walaupun kita mengajar pada sekelompok peserta didik, namun pada hakikatnya yang ingin kita capai adalah perubahan perilaku setiap peserta didik. Semakin tinggi standar keberhasilan ditentukan, maka semakin berkualitas proses pembelajaran. ${ }^{15}$

\section{d. Integritas}

Mengajar harus dipandang sebagai usaha mengembangkan seluruh pribadi peserta didik. Mengajar bukan hanya mengembangkan kemampuan kognitif saja, akan tetapi juga meliputi pengembangan aspek afektif dan aspek psikomotor. Oleh karena itu, strategi pembelajaran harus dapat mengembangkan seluruh aspek kepribadian peserta didik secara terintegrasi.

\section{Pendidikan Agama Islam}

Menurut Kamus Besar Bahasa Indonesia, kata "pendidikan" berasal dari kata dasar didik dan awalan men, menjadi mendidik yaitu kata kerja yang artinya memelihara dan memberi latihan (ajaran). Pendidikan sebagai kata benda berarti proses perubahan sikap dan tingkah laku seseorang atau kelompok orang dalam usaha mendewasakan manusia melalui upaya pengajaran dan latihan. ${ }^{16}$

Sedangkan menurut Rechey dalam bukunya Planning for Teaching, an Introduction, menyatakan pengertian pendidikan sebagai berikut:

Istilah pendidikan berkenaan dengan fungsi yang luas dari pemeliharaan dan perbaikan kehidupan suatu masyarakat terutama membawa warga masyarakat yang baru (generasi muda) bagi penuaian kewajiban dan tanggung jawabnya di dalam masyarakat". 17

15 Wina Sanjaya, Kurikulum dan Pembelajaran, op. cit., h. 132.

${ }^{16}$ Departemen Pendidikan dan Kebudayaan RI, Kamus Besar Bahasa Indonesia (Cet. XI; Jakarta: Balai Pustaka, 2010), h. 702.

${ }^{17}$ Ahmad Tafsir, dkk, Cakrawala pemikiran pendidikan Islam (Bandung: Mimbar Pustaka, 2004), h. 277. 
Secara terminologis, para ahli pendidikan mendefinisikan kata pendidikan dari berbagai tinjauan. Hasan Langgulung melihat arti pendidikan dari sisi fungsi pendidikan, yaitu: pertama, dari segi pandangan masyarakat, dimana pendidikan merupakan upaya pewarisan kebudayaan yang dilakukan oeh genarsai tua kepada generasi muda agar kehidupan masyarakat tetap berkelanjutan. Kedua, dari segi kepentingan individu, pendidikan diartikan sebagai upaya pengembangan potensipotensi yang tersembunyi dan dimiliki manusia. ${ }^{18}$

Sedangkan definisi pendidikan yang disandarkan pada makna dan aspek serta ruang lingkungannya, dapat dilihat apa yang dikemukakan oleh Ahmad D. Marimba, bahwa pendidikan adalah bimbingan atau pimpinan secara sadar oleh pendidik terhadap perkembangan jasmani dan rohani terdidik menuju terbentuknya kepribadian utama. Dalam sistem pendidikan nasional, istilah pendidikan diartikan sebagai usaha sadar untuk meyiapkan peserta didik melalui bimbingan, pengajaran, dan latihan bagi peranannya di masa yang akan datang. ${ }^{19}$

Dari beberapa pendapat para ahli dapat diketahui bahwa pendidikan merupakan aktivitas yang disengaja dan bertujuan yang di dalamnya terlibat berbagai faktor yang saling berkaitan antara satu dengan lainnya, sehingga membentuk satu sistem yang saling mempengaruhi.

Adapun definisi pendidikan agama Islam menurut pendapat beberapa pakar adalah sebagai berikut:

a. Menurut Abdul Majid dan Dian Andayani dalam buku Pendidikan Agama Islam Berbasis Kompetensi bahwa Pendidikan agama Islam adalah upaya sadar dan terencana dalam menyiapkan peserta didik untuk

\footnotetext{
${ }^{18}$ Ibid., h. 278-279.

${ }^{19}$ Ibid.
}

mengenal, memahami, menghayati, hingga mengimani, ajaran agama Islam, dibarengi dengan tuntunan untuk menghormati penganut agama lain dalam hubungannya dengan kerukunan antar umat beragama hingga terwujud kesatuan dan persatuan bangsa. ${ }^{20}$ Dalam hal ini, pendidikan agama Islam merupakan suatu aktivitas yang disengaja untuk membimbing manusia dalam memahami dan menghayati ajaran agama Islam serta dibarengi dengan tuntutan untuk menghormati penganut agama lain.

b. Menurut Zakiyah Daradjat yang disitir oleh Abdul Majid dan Dian Andayani bahwa pendidikan agama Islam adalah suatu usaha untuk membina dan mengasuh peserta didik agar senantiasa dapat memahami ajaran Islam secara menyeluruh. Lalu menghayati tujuan, yang pada akhirnya mengamalkan serta menjadikan Islam sebagai pandangan hidup. ${ }^{21}$ Di sini, pendidikan agama Islam tidak hanya bertugas menyiapkan peserta didik dalam rangka memahami dan menghayati ajaran Islam namun sekaligus menjadikan Islam sebagai pedoman hidup.

c. Menurut Azizy yang dikutip oleh Abdul Majid dan Dian Andayani mengemukakan bahwa esensi pendidikan yaitu adanya proses transfer nilai, pengetahuan, dan ketrampilan dari generasi tua kepada generasi muda agar generasi muda mampu hidup. Oleh karena itu ketika kita menyebut pendidikan agama Islam, maka akan mencakup dua hal (a) mendidik siswa untuk berperilaku sesuai dengan nilai-

20 Abdul Majid dan Dian Andayani, Pendidikan Agama Islam Berbasis Kompetensi (Konsep dan Implementasi Kurikulum 2004) (Bandung: PT Remaja Rosdakarya), h. 130.

${ }^{21}$ Ibid. 
nilai atau akhlak Islam; (b) mendidik siswa-siswi untuk mempelajari materi ajaran Islam subjek berupa pengetahuan tentang ajaran Islam. ${ }^{22}$

d. Menurut Ahmad Supardi yang dikutip oleh Ahmad Tafsir, dkk bahwa pendidikan agama Islam merupakan pendidikan yang berdasarkan Islam atau tuntunan agama Islam dalam membina dan membentuk pribadi muslim yang bertaqwa kepada Allah SWT, cinta kasih sayang pada orang tuanya dan sesama hidupnya dan juga kepada tanah airnya sebagai karunia yang diberikan oleh Allah SWT. ${ }^{23}$ Dalam hal ini pendidikan Islam adalah suatu bimbingan yang dilakukan untuk membentuk pribadi muslim yang cinta kepada tanah air dan sesama hidup.

Jadi pendidikan agama Islam merupakan usaha sadar yang dilakukan guru dalam rangka mempersiapkan peserta didik untuk menyakini, memahami, dan mengamalkan ajaran Islam melalui kegiatan bimbingan, pengajaran atau pelatihan yang telah ditentukan untuk mencapai tujuan yang ditetapkan.

\section{Pribadi Muslim yang Islami}

1. Pengertian Pribadi Muslim yang Islami

Secara etimologi, kepribadian berasal dari kata "pribadi" yang berarti manusia sebagai perseorangan, keseluruhan sifat yang merupakan watak manusia, keadaan manusia sebagai perseorangan. Kemudian kata itu mendapat awalan "ke" dan akhiran "an" yang berarti sifat hakiki yang tercermin pada sikap seseorang yang membedakan dirinya dengan orang lain. ${ }^{24}$

\footnotetext{
${ }^{22}$ Ibid., h.131.

${ }^{23}$ Ahmad Tafsir, dkk, op. cit., h. 285.

${ }^{24}$ Departemen Pendidikan dan Kebudayaan RI, Kamus Besar Bahasa Indonesia (Cet. XI; Jakarta: Balai Pustaka, 2010), h.780.
}

Kata ini dalam bahasa Inggris adalah "Personality" yang berasal dari kata Persona (bahasa Latin) yang berarti kedok atau topeng. Yaitu penutup muka yang sering dipakai oleh pemain panggung. Maksudnya untuk menggambarkan prilaku dan watak atau pribadi seseorang. ${ }^{25}$

Secara terminologi, kepribadian adalah ciri atau karakteristik atau gaya atau sifat khas dari diri seseorang yang bersumber dari bentukan-bentukan yang diterimadari lingkungan, misalnya, keluarga masa kecil, dan juga bawaan seseorang sejak lahir. ${ }^{26}$ Kepribadian (personality) merupakan salah satu kajian psikologi yang lahir berdasarkan pemikiran, kajian atau temuan-temuan (hasil praktik penanganan kasus) para ahli. Objek kajian kepribadian adalah "human behavior", perilaku manusia yang pembahasannya terkait dengan apa, mengapa dan bagaimana perilaku tersebut. ${ }^{27}$ Kepribadian merupakan pengaturan individu yang bersifat dinamis pada sistem fisik dan psikis yang menentukan tabiatnya serta selaras dengan lingkungannya. ${ }^{28}$ Sigmund Freud mengungkapkan bahwa kepribadian adalah integrasi dari landasan, ego dan super ego. Landasan sebagai komponen kepribadian psikologis, ego sebagai komponen psikologis, dan super ego sebagai komponen kepribadian sosiologis. ${ }^{29}$

Schultz mengungkapkan bahwa konsep awal dari kepribadian adalah tingkah

25 M. Enoch, Anak, Keluarga dan Masyarakat (Cet. III; Jakarta: Pustaka Sinar Harapan, 1991), h. 75.

26 Sjarkawi, Pembentukan Kepribadian Anak: Peran Moral, Intelektual, Emosional, and Sosial sebagai Wujud Integritas Membangun Jati Diri, (Jakarta: PT. Bumi Aksara, 2008), h. 11.

27 Syamsu Yusuf dan A dan Juntika Nurihsan, op. cit., h. 1.

${ }^{28}$ Rahmat Ramadhana Al Banjari, Membaca Kepribadian Muslim seperti Membaca Al-Qur'an (Yogyakarta: Diva Press, 2008), h. 168.

29 Nety Hartati, Islam dan Psikologi, (Jakarta: PT. Raja Grafindo Persada, 2004), h. 121. 
laku yang ingin ditunjukkan kepada lingkungan sosial dan kesan mengenai diri yang diinginkan agar dapat ditangkap oleh orang lain. ${ }^{30}$

J. F. Dasbid menyebut kepribadian sebagai nurani seluruh tingkah laku seseorang. Selanjutnya William Stern, seorang pakar ilmu jiwa menyatakan bahwa kepribadian merupakan gambaran totalitas yang penuh arti dalam diri seseorang yang ditujukan kepada suatu tujuan tertentu secara bebas. ${ }^{31}$

Menurut Phares berpendapat kepribadian merupakan pola khas dari fikiran, perasaan serta tingkah laku yang membedakan orang yang satu dengan yang lainnya dan tidak tidak berubah lintas waktu dan situasi. ${ }^{32}$ Sedangkan G. W. All Port, berpendapat bahwa kepribadian merupakan organisasi yang dinamis dari sistem-sistem psikofisik dalam diri individu yang menentukan penyesuaian yang unik terhadap karakteristik perilaku dan pemikirannya. ${ }^{33}$

Kepribadian dapat dilihat dari empat aspek muatannya. Pertama, aspek personalia, yaitu kepribadian dilihat dari pola tingkah laku lahir dan batin yang dimiliki seseorang. Kedua, aspek individualitas, yakni karakteristik atau sifatsifat khas yang dimiliki seseorang secara individu berbeda dengan individu lainnya. Ketiga, aspek mentalis, sebagai perbedaan yang berkaitan dengan cara berfikir. Keempat, aspek identitas, yaitu

30 Dede Rahmat Hidayat, Psikologi Kepribadian dalam Konseling (Jakarta: Ghalia Indonesia, 2011), h. 6.

31 Jalaluddin dan Abdullah Idi, Filsafat Pendidikan Islam (Yogyakarta: Ar-Ruzz Media, 2007), h. 180.

${ }^{32}$ Alwisol, Psikologi Kepribadian (Malang: Penerbit Universitas Muhammadiyah Malang, 2007), h. 9.

${ }^{33}$ Paulus Budi Raharjo, Mengenal Teori Kepribadian Mutakhir (Yogyakarta: Kanisius, 1997), h. 81 . kecenderungan seseorang untuk mempertahankan sikap dirinya dari pengaruh luar. Identitas merupakan karakteristik seseorang. ${ }^{34}$

Kemudian kata "kepribadian" ditambah dengan "muslim", sehingga menjadi kepribadian muslim. Kepribadian muslim sendiri berarti kepribadian yang menunjukkan tingkah laku luar, kegiatankegiatan jiwa, filsafat kehidupan dan kepercayaan seorang Islam. ${ }^{35}$ Dengan kata lain, kepribadian muslim adalah tingkah laku seorang muslim yang dimiliki oleh seseorang dan menjadi ciri khas kepribadian yang membedakan seseorang tersebut dengan orang lain, karena sikap dan tingkah lakunya menunjukkan pengabdian kepada Tuhan, penyerahan diri kepadaNya. Kepribadian muslim adalah "pengalaman sepenuhnya ajaran Allah dan Rasulnya". 36

Kepribadian Muslim merupakan identitas yang dimiliki oleh seseorang sebagai ciri khas dari keseluruhan tingkah laku lahiriyah maupun batiniyah. ${ }^{37}$ Kepribadian manusia yang ideal menurut Islam, dicontohkan pada sosok Nabi Muhammad Saw. Pada diri beliaulah yang sebenar-benarnya terjadi keseimbangan antara tubuh dan jiwa sehingga mewujudkan bentuk kepribadian yang hakiki dan sempurna. ${ }^{38}$

Kepribadian muslim adalah kepribadian yang seluruh aspek-aspeknya merealisasikan atau mencerminkan ajaran

\footnotetext{
${ }^{34}$ Jalaluddin dan Abdullah Idi, op. cit., h. 190.

${ }^{35}$ Sidi Gazalba, Pendidikan Umat Islam (Cet. IV; Jakarta: Rajawali Pers, 1994), h. 92.

${ }^{36}$ Abu Ahmadi dan Noor Salimi. DasarDasar Pendidikan Agama Islam (Jakarta: Bumi Aksara, 2004), h. 69.

${ }^{37}$ Abdul Khobir, Filsafat Pendidikan Islam (Pekalongan STAIN Pekalongan Press, 2007), h. 129.

38 Purwa Atmaja Prawita, Psikologi Kepribadian dengan Perspektif Baru, (Jogjakarta: Ar-Ruzz Media, 2013) h. 332.
} 
Islam. Kepribadian muslim juga dapat diartikan kepribadian yang seluruh aspekaspeknya baik tingkah laku luarnya, kegiatan-kegiatan jiwanya maupun filsafat hidup dan kepercayaan menunjukkan pengabdian kepada Tuhan dan penyerahan diri kepadaNya. Menurut Muhammad Zein bahwa kepribadian muslim tidak akan terlepas dari tiga aspek yaitu: Iman, Islam dan Ihsan. ${ }^{39}$ Sedangkan faktor pendidikan akhlak dilakukan dengan cara mempengaruhi dengan menggunakan usaha membentuk kondisi yang mencerminkan pola kehidupan yang sejalan dengan normanorma Islam contoh teladan dan lingkungan yang serasi. $^{40}$

Berdasarkan pendapat para pakar menegenai kepribadian muslim maka dapat diketahui bahwa, kepribadian muslim adalah cirri khas seseorang yang membedakan dia dengan yang lainnya dari keseluruhan tingkah laku lahiriyah maupun batiniyah yang dapat dibentuk melalui faktor internal (bawaan) dan faktor eksternal (lingkungan).

2. Struktur Kepribadian Muslim yang Islami

Struktur kepribadian adalah aspekaspek atau elemen-elemen yang terdapat pada diri manusia yang karenanya kepribadian terbentuk. ${ }^{41}$ Pada dasarnya aspek-aspek kepribadian itu dapat dibagi menjadi tiga, yaitu:

a. Kejasmanian, meliputi tingkah laku luar yang mudah Nampak dan ketahan dari luar, misalnya: cara-caranya berbuat, caranya berbicara, dan sebagainya.

b. Kejiwaan, meliputi aspek-aspek yang tidak dapat segera dilihat dan ketahuan

\footnotetext{
${ }^{39}$ Hamdani Ihsan dan Fuad Ihsan, Filsafat Pendidikan Islam (Cet. Ke-2 revisi; Bandung: Pustaka Setia, 2001) h. 20.

${ }^{40}$ Abdul Khobir, op.cit., h. 134.

${ }^{41}$ Abdul Mujib, Perencanaan Pembelajaran Mengembangkan Standar Kompetensi Guru (Bandung: PT. Remaja Rosdakarya, 2007), h. 56.
}

dari luar, missal: cara-caranya berfikir, sifat, dan minat.

c. Kerohanian yang luhur, meliputi aspek-aspek kejiwaan sitem nilai-nilai yang telah meresap dalam kepribadian itu yang mengarahkan dan memberi corak seluruh kehidupan individu itu. Bagi orang-orang yang beragama, aspek-aspek inilah yang menentukan kemana arah kebahagiaan, bukan saja di dunia tetapi juga di akhirat. Aspek-aspek inilah yang memberi kualitas kepribadian keseluruhannya. ${ }^{42}$

\section{c. Berakhlak Mulia}

Akhlak artinya tabiat, budi pekerti atau kebiasaan. ${ }^{43}$ Manusia yang berakhlak adalah manusia yang suci dan sehat hatinya, sedangkan manusia yang tidak berakhlak adalah manusia yang kotor hatinya. Manusia yang berakhlak (husn al-khuluq) akan tertanam iman dan hatinya, sebaliknya manusia yang tidak berakhlak (su'ul alkhuluq) ialah manusia yang ada sikap mendua dalam tuhan (nifaq) di dalam hatinya. ${ }^{44}$ Kembali kepada kebenaran dengan melakukan tobat dari segala kesalahan yang pernah dibuat sebelumnya. ${ }^{45}$

\section{Metode Penelitian}

Jenis penelitian ini adalah kualitatif. Penelitian kualitatif adalah prosedur penilitian yang menghasilkan data deskriptif berupa kata-kata tertulis atau lisan dari

${ }^{42}$ Ahmad D. Marimba, Pengantar Filsafat Pendidikan Islam (Bandung: Al Ma'arif, 1962), h. 66-67.

\footnotetext{
${ }^{43}$ Mawardi Lubis, Evaluasi Pendidikan Nilai (Jogjakarta: Pustaka Pelajar, 2008), h. 26

${ }^{44}$ M. Abduh Malik, dkk, Pengembangan Kepribadian Pendidikan Agama Islam (Jakarta: Departemen Agama, 2009), h. 78.

45 Jalaluddin dan Usman Said, Filasafat Pendidikan Islam: Konsep dan Perkembangan Pemikirannya (Jakarta: PT. Raja Grafindo Persada, 1994), h. 96-97.
} 
orang-orang dan perilaku yang dapat diamati. ${ }^{46}$ Penelitian kualitatif dalam penelitian ini bertujuan untuk menemukan persepsi guru pendidikan agama dalam membentuk kepribadian muslim peserta didik.Pendekatan yang digunakan pada penelitian ini adalah pendekatan interdisipliner, antara lain: pendekatan manajeman, pedagogis, sosiologis, dan psikologis. Penelitian ini menggunakan 2 (dua) jenis sumber data, yaitu: Data Primer, dalam penelitian lapangan data primer merupakan data utama yang diambil langsung dari para informan yang dalam hal ini adalah guru Pendidikan Agama Islam. Data ini berupa hasil interview (wawancara) dan Data Sekunder, pengambilan data dalam bentuk dokumen-dokumen yang telah ada serta hasil penelitian relevan yang ditemukan peneliti. Data ini berupa dokumentasi penting menyangkut profil sekolah, teori tentang konsep strategi pembelajaran, pendidikan agama Islam, dan pembentukan kepribadian muslim.Peneliti terlibat langsung di lokasi penelitian untuk mengadakan penelitian dan memperoleh data-data konkret yang ada hubungannya dengan pembahasan ini. Teknik pengumpulan data yang digunakan peneliti yakni observasi atau pengamatan cara-cara menganalisis dan mengadakan pencatatan secara sistematis mengenai tingkah laku dengan melihat atau mengamati individu atau kelompok secara langsung. ${ }^{47}$ Untuk melaksanakan analisis data kualitatif ini maka perlu ditekankan beberapa tahapan dan langkah-langkah yaitu reduksi kata dan penyajian data serta verifikasi.

46 Basrowi dan Suwandi, Memahami Penelitian Kualitatif (Cet. I; Jakarta: Rineka Cipta, 2008), h. 21.

${ }^{47}$ Ibid., h. 93.

\section{Hasil Penelitian}

1. Strategi Guru Pendidikan Agama Islam pada Pembelajaran Pendidikan Agama Islam dalam Pembentukan Kepribadian Muslim Peserta Didik

Seorang guru harus mengetahui tugas dan tanggung jawabnya sebagai pendidik. Guru disamping memiliki tugas mengajar, juga bertanggung jawab terhadap pencapian pembelajaran peserta didiknya. Pencapaian pembelajaran harus memenuhi tiga aspek, yaitu kognitif, psikomotorik dan afektif.

Dalam upaya guru membentuk kepribadian muslim peserta didik melalui pembelajaran Pendidikan Agama Islam, guru menggunakan dua strategi pembelajaran, yaitu:

1. Pembelajaran Langsung (Direct Instruction)

Pembelajaran langsung mengutamakan proses belajar konsep dan keterampilan motorik, sehingga menciptakan suasana pembelajaran yang lebih terstruktur. pembelajaran ini biasanya dilakukan di dalam kelas, pelaksanaannya terencana dan materinya diatur kurikulim. ${ }^{48}$

Guna suksesnya strategi pembelajaran diperlukan pemilihan metode pembelajaran yang tepat. Hal ini sangat mempengaruhi daya serap peserta didik terhadap materi ajar dan diharapkan pengetahuan keislaman dapat menjadi tameng bagi peserta didik terhadap perilaku menyimpang yang menafikannya dari ciri kepribadian muslim. Agar materi tersebut tidak sekedar diketahui untuk diujiankan atau sekedar menjalankan tuntutan kurikulum dan tugas. Adapun beberapa hal yang bisa digunakan dalam pembelajaran Pendidikan Agama Islam, yaitu:

\footnotetext{
${ }^{48}$ Andi Ismail Saleh, Wawancara, 14 Januari
} 2016. 
a. Metode Persuasif

Pendekatan kepada peserta didik mulai dari pengetahuan kondisi, motivasi, tingkat kecerdasan sampai latar belakang peserta didik sangat diperlukan dalam pembelajaran. Inilah nantinya yang dijadikan dasar oleh guru untuk menentukan arah pembelajaran selanjutnya.

\section{b. Kisah yang Berisi Targīb dan Tarhīd}

Kisah yang dimaksudkan bukan dalam arti sempit, yang diceritakan kepada peserta didik tidak harus dari kisah sahabat Nabi atau tokoh-tokoh Islam. Inilah salah satu alasan mengapa guru harus berwawasan luas, terutama harus memiliki wawasan tentang materi yang diajarkan karena fakta yang relevan dengan pentingnya sikap disiplin, tanggung jawab, dan saling menghargai dapat menjadi bahan ajar yang kemudian dikemas dalam bentuk cerita. ${ }^{49}$

Menurut Andi Ismail Saleh, berdasarkan pengalamannya menggunakan metode kisah yang dikolaborasikan dengan Targhib dan Tarhid pada pembelajaran Pendidikan Agama Islam, disamping menceritakan fakta yang relevan terkadang dia berdongeng. Dimana dalam dongeng tersebut ada pelajaran yang dapat dipetik kaitannya dengan pentingnya sikap religius, disiplin, dan saling menghargai, sehingga dapat terbentuk kepribadian muslim pada diri peserta didik. ${ }^{50}$

c. Metode Pengambilan Pelajaran dan Peringatan (Nasihat)

Dalam metode pengambilan pelajaran dan peringatan kaitannya pembentukan kepribadian muslim peserta didik, guru menggugah hati peserta didik lewat pengambilan pelajaran dan peringatan berupa nasihat agar materi Pendidikan Agama Islam yang telah diajarkan dapat diimplementasikan peserta didik secara

\footnotetext{
${ }^{49}$ Gusmiati, Wawancara, 15 Januari 2016.

${ }^{50}$ Andi Ismail Saleh, Wawancara, 14 Januari
}

sungguh-sungguh dalam kehidupan seharihari.

Pembelajaran tidak langsung (indirect instruction) merupakan strategi pembelajaran yang memperlihatkan bentuk keterlibatan peserta didik yang paling tinggi karena fungsi guru disini hanyalah sebagai fasilitator, peserta didik lebih banyak belajar melalui observasi, penyelidikan, penggambaran inferensi data, pembentukan hipotesis dan kesimpulan.

Strategi pembelajaran ini, peserta didik dituntut dapat memecahkan masalah dalam kehidupannya, mempelajari kasus aktual dan respon seharusnya terhadap kasus tersebut. Sehingga pembelajaran tidak langsung (indirect instruction) dalam pembentukan kepribadian muslim peserta didik dapat mendorong peserta didik untuk berpikir terhadap prilakunya.

\section{a. Sanksi}

Perilaku peserta didik di luar sekolah seperti penggunaan pakaian yang mempertontonkan aurat atau perilaku lain seperti merokok, membolos, balapan liar mesti mendapatkan perhatian berupa respon sanksi mendidik yang memberi efek jera. Sanksi tersebut bisa berupa sanksi yang ada nilai manfaatnya untuk lingkungan seperti membersihkan atau sanksi fisik yang mendidik seperti berdiri dan dilihat oleh semua orang.

Terkadang seorang guru tidak menghiraukan kegiatan peserta didik di luar sekolah. Padahal kesuksesan dari pendidikan dapat di lihat pada kegiatan di luar sekolah. Sehingga bila guru memposisikan dirinya sebagai orang tua, maka akan merasa memiliki tanggung jawab lebih terhadap kebaikan dan keberhasilan peserta didiknya.

2. Faktor Pendukung dan Penghambat Strategi Guru Pendidikan Agama Islam pada Pembelajaran Pendidikan Agama 
Islam dalam Pembentukan Kepribadian Muslim

Manusia dengan akal pikirannya sebelum melaksanakan suatu kegiatan yang sederhana maupun kegiatan yang sifatnya kompleks dengan melibatkan berbagai komponen, terlebih dahulu membuat perencanaan-perencanaan dan mempersiapkan segala sesuatu untuk memperlancar kegiatan tersebut.

1) Ibadah

Upaya pembentukan kepribadian muslim melalui kegiatan ibadah diantaranya adalah sebagai berikut:

a) Pelaksanaan shalat dzuhur berjama'ah di mushallah

Para guru khususnya guru agama mengajak peserta didiknya untuk melaksanakan shalat berjama'ah. Membiasakan peserta didik pergi ke mushallah untuk shalat berjama'ah akan menambah keimanan dan keyakinannya kepada Allah swt dan secara tidak langsung dalam diri peserta didik akan tumbuh rasa kasih sayang terhadap sesama yang dapat memperkuat ukhuwah Islamiyah. Dengan shalat dapat membuat hati peserta didik menjadi damai dan tenang sehingga mereka akan berfikir bahwa dengan shalat dapat menentramkan jiwanya, dengan begitu peserta didik akan semakin rajin dalam melaksanakan shalat lima waktu, dan menjadi diri yang berpribadi muslim.

b) Pengadaan Sarana Prasarana Ibadah

Pengadaan sarana parsarana ibadah ini berupa bangunan mushallah, pengadaan peralatan shalat, Alqur'an dan sebagainya. Pengadaan sarana parasarana ibadah ini diharapkan mampu memotivasi peserta didik untuk melaksanakan ibadah sehingga upaya ini dapat mendukung tercapainya tujuan pendidikan Islam yaitu terbentuknya pribadi muslim. a. Kerja Sama Antar Guru

Adanya komitmen dari semua guru untuk menegakkan aturan demi terbinanya generasi bangsa dan agama yang berIMTAQ dan ber-IPTEK, sangat membantu dalam upaya pembentukan kepribadian muslim peserta didik. Pelanggaranpelanggaran di luar sekolah kaitannya aturan yang berkaitan dengan perilaku yang menodai identitas keislamannya dapat diminimalisir karena peserta didik mendapat pengawasan lebih, mengingat kediaman guru yang menyebar disetiap daerah dan dekat dengan peserta didik. ${ }^{51}$

Fahrul Asnur mengungkapkan bahwa dia menjadi takut untuk keluar malam sebab akan dihukum di sekolah bila ketahuan oleh salah seorang guru. ${ }^{52}$

Begitupun ada kerjasama guru dalam memberi sanksi terhadap peserta didik yang melakukan tindakan indisipliner seperti terlambat, bolos, tidak menggunakan seragam lengkap.

\section{b. Lingkungan Keluarga}

Tidak bisa dipungkiri bahwa waktu guru bersama peserta didik dibatasi oleh jam pelajaran sekolah. Setelah itu peserta didik lebih banyak menghabiskan waktu bersama keluarga khususnya orang tua. Menurut Andi Ismail Saleh ada beberapa lingkungan keluarga sebagai pendukung dalam upaya pembentukan karakter muslim peserta didik, diantaranya:

1) Pendidikan

Peserta didik yang berasal dari keluarga berpendidikan sangat berbeda dengan peserta didik yang berasal dari keluarga kurang berpendidikan. Hal ini

\footnotetext{
${ }^{51}$ Andi Ismail Saleh, Wawancara, 14 Januari 2016.

${ }^{52}$ Fahrul Asnur, (Peserta Didik Kelas XI SMK Muhammadiyah Watansoppeng) Wawancara, 21 Januari 2016
} 
terlihat pada tingkat perhatian peserta didik terhadap pelajaran yang berbeda. Secara umum peserta didik yang berasal dari keluarga berpendidikan tingkat perhatiannya terhadap pelajaran lebih tinggi dari pada peserta didik yang berasal dari keluarga yang kurang berpendidikan. Sehingga tingkat pengamalan terhadap pembelajaran pun berbeda.

2) Prinsip Adat

Peserta didik yang memegang teguh pada budaya. Dalam beberapa daerah atau lingkungan keluarga budaya tersebut masih dipertahankan dan masih sangat kental. Peserta didik yang berasal dari keluarga yang masih memegang teguh perinsip adat dapat mencapai aspek afektif dalam pembelajaran Pendidikan Agama Islam sebagai upaya pembentukan kepribadian muslim walaupun hanya sekedar memahami materi Pendidikan Agama Islam saja.

3) Taat Beragama (Religius)

Sama halnya dengan prinsip adat, peserta didik yang berasal dari keluarga yang religius mampu mencapai rana afektif dalam pembelajaran Pendidikan Agama Islam sebagai pembentuk kepribadian muslim, setelah memahami materi dalam pembelajaran. Menurut Andi Ismail Saleh perilaku dekaden sangat dipengaruhi oleh moral. Hubungannya dengan masyarakat, moral sangat dipengaruhi nilai-nilai kultur (budaya). Dan seiring perkembangannya, budaya sangat dipengaruhi oleh nilai-nilai agama. $^{53}$

Yunita Purnama mengatakan bahwa tugas dan aturan untuk senantiasa menutup aurat saat keluar rumah tidak terlalu berpengaruh bagi dirinya, karena sebelum tugas dan aturan tersebut berlaku padanya dia memang telah terbiasa mengenakan jilbab dan berpakaian Islami karena

\footnotetext{
${ }^{53}$ Andi Ismail Saleh, Wawancara, 14 Januari 2016.
}

dibiasakan oleh keluarga (orang tua) sejak kecil. $^{54}$

\section{Faktor Penghambat}

a. Kurangnya Kesadaran dari Peserta Didik Mengenai Perilaku yang Menunjukkan Kepribadian Muslim

Terkadang beberapa peserta didik hanya mengindahkan tugas dan aturan bila berada dalam pengawasan yang ketat dari guru. Sehingga setelah peserta didik keluar dari lingkungan sekolah dan merasa tidak mendapatkan pengawasan dari guru lagi, dia leluasa melakukan sesuka hatinya.

b. Lingkungan Keluarga dan Masyarakat

Berbedanya latar belakang peserta didik membuat karakter mereka berbeda pula. Perbedaan karakter tentunya membutuhkan penanganan yang bervariasi dalam pembentukan karakter muslim peserta didik. Lingkungan keluarga di samping sebagai pendukung dalam upaya pembentukan karakter muslim peserta didik, juga dapat menjadi penghambat. Tidak semua peserta didik berasal dari keluarga yang meprioritaskan pendidikan, memegang teguh prinsip adat dan religius.

Begitupun pengaruh lingkungan masyarakat (pergaulan) menjadi masalah dalam perkembangan moral peserta didik. Pemikiran dan kebiasaan yang didapat peserta didik lebih banyak dipengaruhi oleh lingkungan serta pesatnya laju perkembangan teknologi informasi sekarang ini. Mayoritas peserta didik mendapatkan informasi tentang gaya berpakaian, variasi kendaraan, sampai mengenai seksualitas melalui media internet atau teman yang juga menjadi sember penerangan utama. ${ }^{55} \mathrm{Hal}$ ini berbanding terbalik dengan hal yang semestinya, yang menyatakan bahwa sesungguhnya pengetahuan seksualitas harus

\footnotetext{
${ }^{54}$ Yunita Purnama, (Peserta Didik Kelas XI SMK Muhammadiyah Watansoppeng), Wawancara, 21 Januari 2016.

${ }^{55}$ Keterangan beberapa peserta didik dalam melakukan penelitian di lokasi penelitian.
} 
lebih banyak diperoleh dari orang tua atau guru yang senantiasa menginginkan kebaikannya.

$$
\text { Dalam mengatasi hambatan- }
$$
hambatan tersebut diatas, jalan yang ditempuh oleh guru sebagai solusi adalah dengan pendekatan persuasif secara individu. Artinya guru memberikan bimbingan dan perhatian khusus serta pendekatan dengan orang tua peserta didik yang bersangkutan, sehingga ada kerja sama dalam pembinaan. ${ }^{56}$

\section{Hasil Penerapan Strategi Guru} Pendidikan Agama Islam pada Pembelajaran Pendidikan Agama Islam dalam Pembentukan Kepribadian

Hasil dari pembelajaran pendidikan agama Islam yang dilaksanakan. Namun, dampak pembelajaran pendidikan agama Islam harus dilihat dari segi kognitif, afektif dan psikomotorik. Pembelajaran pendidikan agama Islam dikatakan berhasil manakala peserta didik dapat memahami materi pendidikan agama Islam sekaligus dapat mengaktualisasikan pemahamannya tersebut dalam kehidupan sehari-hari. Untuk lebih jelasnya akan diuraikan hasil wawancara dengan Gusmiati sebagai berikut:

Berdasarkan pemaparan hasil wawancara tersebut dapat dipahami bahwa dampak pembelajaran Pendidikan Agama Islam tidak bisa langsung dilihat setelah dilaksanakannya pembelajaran. Karena pembelajaran Pendidikan Agama Islam tidak hanya mentransfer materi kepada peserta didik saja namun diperlukan adanya penghayatan terhadap materi sehingga menimbulkan adanya perubahan sikap peserta didik setelah mendapatkan materi tersebut. Jadi, pembelajaran Pendidikan Agama Islam harus mencakup segi kognitif, afektif, dan psikomotorik.

\footnotetext{
${ }^{56}$ Gusmiati, wawancara, Jera'e 15 Januari 2016.
}

\begin{abstract}
Untuk mengetahui mendalam tentang hasil strategi pembelajaran pendidikan agama Islam terhadap kepribadian muslim peserta didik, dapat dilihat pada pemaparan mengenai karakter muslim yang diteliti berikut:
\end{abstract}

1. Religius

Strategi pendidikan agama Islam yang diterapkan oleh guru pendidikan agama Islam berdampak pada:

Pertama, kelancaran peserta didik dalam membaca Al-Qur'an setelah mengikuti ekstrakurikuler IMTAQ. Hal ini terbukti pada hasil tes yang diamati oleh peneliti, ada perkembangan peserta didik dalam membaca Alquran.

Kedua, Sikap dan perilaku peserta didik yang patuh dalam melaksanakan ajaran agama yang dianutnya, dapat dilihat pada kegiatan shalatnya. Dalam melaksanakan shalat berjamaah di Mushallah beberapa peserta didik tidak lagi harus diperintahkan untuk melaksanakan shalat berjamaah zuhur di Mushallah. Selain itu ditemukan peserta didik yang melaksanakan shalat dhuha ketika datang cepat di sekolah tanpa diperintahkan oleh guru. Kesadaran ini muncul dari nasihat oleh guru pendidikan agama Islam. Sebagaimana diungkapkan Wahyudi,

\section{Disiplin}

Diakui Gusmiati bahwa pencapaian dalam pembelajaran Pendidikan Agama Islam sebagai upaya pembentukan kepribadian muslim peserta didik bisa dianggap belum optimal secara menyeluruh terhadap peserta didik.

Kedisiplinan dalam hal menaati aturan sekolah untuk berpakaian Islami pada jam sekolah patut disyukuri. Apalagi pada umumnya peserta didik perempuan menggunakan jilbab pada aktivitas 
kesehariannya baik pada jam sekolah maupun diluar jam sekolah. ${ }^{57}$

Virda Zul Azzahrah mengatakan tugas yang diberikan oleh guru dalam pembelajaran Pendidikan Agama Islam untuk mengenakan jilbab setiap keluar rumah membuatnya menjadi terbiasa memakai jilbab, sehingga bila keluar rumah tanpa mengenakan jilbab, terasa ada yang kurang dalam penampilannya. ${ }^{58}$ Begitupun Nurfadillah mengungkapkan bahwa tugas untuk menutup aurat dari guru dalam pembelajaran Pendidikan Agama Islam membuatnya merasa nyaman bila mengenakan jilbab dan malu bila tidak mengenakannya. ${ }^{59}$

\section{Menghargai Sesama}

Dalam membentuk kepribadian muslim peserta didik, maka sekolah perlu turut menciptakan lingkungan yang kondusif untuk menumbuhkan keimanan dan ketaqawaan peserta didik melalui pembiasaan dan pembinaan moral peserta didik melaui kegiatan-kegiatan religius.

Dari hasil observasi dan wawancara di sekolah, dapat diketahui bahwa pembiasaan-pembiasaan yang dilaksanakan melalui pembiasaan berjabat tangan ketika bertemu, senyum dan mengucapkan salam ketika bertemu guru misalnya, hal tersebut menjadikan lebih akrab dengan guru sehingga berpengaruh pada penghargaannya terhadap guru. Kemudian pembinaan moral peserta didik dilakukan dengan nasihat, kegiatan keagamaan dan sebagainya. Dari upaya tersebut sangat berpengaruh terhadap perubahan sikap peserta didik.

2016.

${ }^{57}$ Wahyudi, wawancara, Jera'e 21 Januari

\section{E. Kesimpulan}

Berdasarkan hasil penelitian yang diuraikan pada pembahasan sebelumnya, maka penulis menarik kesimpulan sebagai berikut: 1. Sebagai upaya membentuk kepribadian muslim peserta didik, guru Pendidikan Agama Islam menggunakan dua strategi pembelajaran, yaitu pembelajaran langsung (direct instruction) dan pembelajaran tidak langsung (indirect instruction). Adapu faktor pendukung strategi guru Pendidikan Agama Islam pada pembelajaran Pendidikan Agama Islam dalam pembentukan kepribadian muslim peserta didik adalah: 1) Kebijakan sekolah, 2) Kerja sama antar pendidik, 3) Lingkungan keluarga dan masyarakat. Adapun faktor penghambatnya adalah: 1) Kurangnya kesadaran dari peserta didik mengenai perilaku yang menunjukkan kepribadian muslam, 2) Lingkungan keluarga dan masyarakat. Sehingga hasil Penerapan Strategi Guru Pendidikan Agama Islam pada Pembelajaran Pendidikan Agama Islam dalam pembentukan kepribadian muslim peserta didik berdampak baik pada perilaku religius, disiplin, dan menghargai sesama, namun masih perlu dilakukan perbaikan dan perhatian khusus dalam hal pembentukan perilaku disiplin.

\section{DAFTAR PUSTAKA}

Ahmadi, Abu, dan Salimi, Noor. Dasardasar Pendidikan Agama Islam. Jakarta: Bumi Aksara, 2004.

Alwisol. Psikologi Kepribadian. Malang: Penerbit Universitas Muhammadiyah Malang, 2007.
Arifin, M. Kapita Selekta Pendidikan. Cet. IV; Jakarta: Bumi Aksara, 2000. 
. Psikologi Dakwah. Jakarta:

Bumi Aksara, 2000.

Al-Banjari, Rahmat Ramadhana. Membaca Kepribadian Muslim seperti Membaca Al-Qur'an. Yogyakarta: Diva Press, 2008.

Basrowi, dan Suwandi. Memahami Penelitian Kualitatif. Cet. I; Jakarta: Rineka Cipta, 2008.

Darajat, Zakiah. Ilmu Jiwa Agama. Jakarta: Bulan Bintang, 1996.

Departemen Agama RI. Al-Qur'an dan Terjemahannya. Jakarta: Pustaka Assalam, 2010.

Departemen Pendidikan dan Kebudayaan RI, Kamus Besar Bahasa Indonesia. Cet. XI; Jakarta: Balai Pustaka, 2010.

Depdiknas, Undang-undang Sistem Pendidikan Nasional. Jakarta: Direktorat Jendral Pendidikan dan Kebudayaan, 2003.

Djamarah, Syaiful Bahri, dan Zain, Azwan. Strategi Belajar Mengajar. Jakarta: PT. Rineka Cipta, 2006.

Djamarah, Syaiful Bahri, (et.al.). Konsep Belajar dan Pembelajaran. Cet. III; Jakarta: Rineka Cipta, 2006.

Elmubarok, Zaim. Membumikan Pendidikan Nilai. Bandung: Alfabeta: 2008.

Enoch, M. Anak, Keluarga dan Masyarakat. Cet. III; Jakarta: Pustaka Sinar Harapan, 1991.

Gazalba, Sidi. Pendidikan Umat Islam. Cet. IV; Jakarta: Rajawali Pers, 1994.
Hamalik, Oemar. Kurikulum dan Pembelajaran. Jakarta: PT. Bumi Aksara, 2002.

Hartati, Nety. Islam dan Psikologi. Jakarta: PT. Raja Grafindo Persada, 2004.

Hidayat, Dede Rahmat. Psikologi Kepribadian dalam Konseling. Jakarta: Ghalia Indonesia, 2011.

Ihsan, Hamdani, dan Ihsan, Fuad. Filsafat Pendidikan Islam. Cet. II revisi; Bandung: Pustaka Setia, 2001.

Jalaluddin, dan Idi, Abdullah. Filsafat Pendidikan Islam. Yogyakarta: ArRuzz Media, 2007.

Jalaluddin. Psikologi Agama. Cet. I; Jakarta: Grafindo Persada, 1996.

Jalaluddin, dan Said, Usman. Filasafat Pendidikan Islam: Konsep dan Perkembangan Pemikirannya. Jakarta: PT Raja Grafindo Persada, 1994.

Khobir, Abdul. Filsafat Pendidikan Islam. Pekalongan STAIN Pekalongan Press, 2007.

Lubis, Mawardi. Evaluasi Pendidikan Nilai. Jogjakarta: Pustaka Pelajar, 2008.

Majid, Abdul, dan Andayani, Dian. Pendidikan Agama Islam Berbasis Kompetensi: Konsep dan Implementasi Kurikulum 2004. Bandung: PT Remaja Rosdakarya.

Malik, M. Abduh, dkk. Pengembangan Kepribadian Pendidikan Agama Islam. Jakarta: Departemen Agama, 2009. 
Marimba, Ahmad D. PengantarFilsafatPendidikan Islam. Bandung: Al Ma'arif, 1962.

Moleong, Lexy J. Metodologi Penelitian Kualitatif. Bandung: Remaja Rosdakarya Offset, 2003.

Mudhafir, Fadhlan. Krisis dalam Pendidikan Islam. Cet. I; Jakarta: Al-Mawardi Prima, 2000.

Mujib, Abdul. Perencanaan Pembelajaran Mengembangkan Standar Kompetensi Guru. Bandung: PT. Remaja Rosdakarya, 2007.

Mulyasa, E. Kurikulum Tingkat Satuan Pendidikan. Bandung: Remaja Rosdakarya, 2006.

Mustahu. Menata Ulang Pemikiran Sistem Pendidikan. Yogyakarta: S.I. Press, 2004.

Al-Nahdlawi, Abdurrahman. Ushul alTarbiyah al-Islamiyah wa Asalibuha fi al-Bayt wa alMadrasah wa al-Mujtama' diterjemahkan oleh Shibabuddin dengan judul "Pendidikan Islam di Rumah, Sekolah dan Masyarakat". Cet. II; Jakarta: Gema Insani Press, 1995.

Nizar, Samsul. Dasar-dasar Pemikiran Pendidikan Islam. Cet. I; Jakarta: Gaya Media Pratama, 2001.

Ondeng, Syarifuddin. Islam dalam Berbagai Dimensi; Kajian tentang Agama, Sejarah dan Pendidikan. Cet. I; Makassar: Berkah Utami, 2004
Prawita, Purwa Atmaja. Psikologi Kepribadian dengan Perspektif Baru. Jogjakarta: Ar-Ruzz Media, 2013.

Purwanto, Ngalim. Psikologi Pendidikan. Bandung: PT. Remaja Rosda Karya, 2007.

Raharjo, Paulus Budi. Mengenal Teori Kepribadian Mutakhir (Yogyakarta: Kanisius, 1997.

Ramayulis, M. Ilmu Pendidikan Islam. Jakarta: Kalam Mulia, 2002.

Rasyid, Harun. Metode Penelitian Kualitatif Bidang Ilmu Sosial dan Agama. Pontianak: STAIN Pontianak, 2000.

Sagala, Syaiful. Konsep dan Makna Pembelajaran. Bandung: Alfabeta, 2003.

Sanjaya, Wina. Kurikulum dan Pembelajaran, Teori dan Praktik Pengembangan KTSP. Cet. I; Jakarta: Kencana, 2008.

\section{Strategi Pembelajaan Berorientasi Standar Proses Pendidikan. Cet. IV; Jakarta: Prenada Media Group, 2008.}

Sjarkawi. Pembentukan Kepribadian Anak: Peran Moral, Intelektual, Emosional, and Sosial sebagai Wujud Integritas Membangun Jati Diri. Jakarta: PT. Bumi Aksara, 2008.

Slameto, Belajar dan Faktor-faktor yang Mempengaruhinya. Jakarta: Rineka Cipta, 2003. 
Sugiyono. Metode Penelitian Kuantitatif Kualitatif dan $R$ \& $D$. Cet. VI; Bandung: Alfabeta, 2009.

Suharto, Toto. Filsafat Pendidikan Islam. Jogjakarta: Ar-Ruzz Media, 2006.

Suprayogo Imam, dan Tobroni. Metode Penelitian Sosial-Agama. Bandung: Remaja Rosdakarya, 2001.

Surachman, Wiranto. Metodologi Pengajaran Nasional. Bandung: CV. Jenmarsit, t.th..

Tafsir, Ahmad, dkk. Cakrawala pemikiran pendidikan Islam. Bandung: Mimbar Pustaka, 2004.
Tim Pakar Yayasan Jati Diri Bangsa, Pendidikan Karakter di Sekolah: Dari Gagasan ke Tindakan. Jakarta: PT Elex Media Komputindo, 2011.

Tohirin. Psikologi Pembelajaran PAI. Jakarta: PT RajaGrafindo Pesada, 2005.

Usman, Husaini, dan Akbar, Purnomo Setiadi. Metodologi Penelitian Sosial. Jakarta: Bumi Aksara, 2008.

UU RI No. 20 Tahun 2003 tentang Sistem Pendidikan Nasional. Jogjakarta: Media Wacana Press, 2003.

Zuhairini, dkk. Filsafat Pendidikan Islam. Jakarta: Bumi Aksara, 2009. 